Discussion Paper No. 04-49

\title{
Children in Need of Medical Innovation
}

Horst Entorf, Jörg Fegert and Michael Kölch

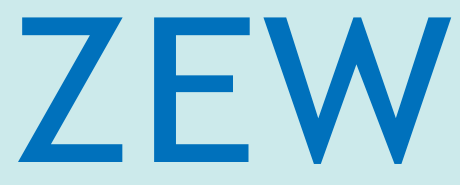

Zentrum für Europäische Wirtschaftsforschung $\mathrm{GmbH}$

Centre for European

Economic Research 
Discussion Paper No. 04-49

\title{
Children in Need of Medical Innovation
}

\author{
Horst Entorf, Jörg Fegert and Michael Kölch
}

Download this ZEW Discussion Paper from our ftp server:

ftp://ftp.zew.de/pub/zew-docs/dp/dp0449.pdf

Die Discussion Papers dienen einer möglichst schnellen Verbreitung von neueren Forschungsarbeiten des ZEW. Die Beiträge liegen in alleiniger Verantwortung der Autoren und stellen nicht notwendigerweise die Meinung des ZEW dar.

Discussion Papers are intended to make results of ZEW research promptly available to other economists in order to encourage discussion and suggestions for revisions. The authors are solely responsible for the contents which do not necessarily represent the opinion of the ZEW. 
Non-technical Summary: Children are therapeutic orphans and an underprivileged group in innovations derived from drug therapy. As the innovation process of pharmaceuticals is a long, risky and very costly business, economists typically emphasise lack of profit incentives and small market size as the most important obstacles to child-related innovative activity. Moreover, as new drugs need to be tested in medical trials, there are ethical concerns leading to a climate of reluctance towards medical trials on persons who are not able to give their "informed consent". Particularly in Germany, due to various reasons, a rather restrictive legislation is to be assumed, characterized by the idea of putting the protection of the individual human being before a more utilitarian view. Thus, economic incentives, legal restrictions and ethical concerns seem to be responsible for the lack of innovative activity targeted at drugs for children, though social cost-benefit considerations (i.e. welfare analysis) would most probably predict a high gain from the introduction of critical innovations. Grounded on a highly interdisciplinary view based on medical, pharmaceutical, psychopharmaceutical, psychotherapeutic and economic research as well as on ethical restrictions, this survey aims at analysing channels of influence that might be helpful both in the analysis of the innovation process of drugs for children, and in improving the uncertain situation of pediatric therapy. 


\title{
Children in Need of Medical Innovation
}

\author{
Horst Entorf, Jörg Fegert, and Michael Kölch
}

July 2004

\begin{abstract}
Summary: As the innovation process of pharmaceuticals is a long, risky and very costly business, economists typically emphasise lack of profit incentives and small market size as the most important obstacles to child-related innovative activity. Moreover, there are ethical concerns because children are not able to give their "informed consent" to requested clinical trials. Thus, economic incentives, legal restrictions and ethical concerns seem to be responsible for the lack of innovative activity targeted at drugs for children, though social costbenefit considerations (i.e. welfare analysis) would most probably predict a high gain from the introduction of critical innovations. Grounded on a highly interdisciplinary view based on medical, pharmaceutical and economic research, this survey aims at analysing channels of influence that might be helpful both in the analysis of the innovation process of drugs for children, and in improving the uncertain situation of pediatric therapy.
\end{abstract}

\section{Authors:}

Prof. Dr. H. Entorf

Prof. Dr. J. M. Fegert

Dr. M. Kölch

Department of Economics

Darmstadt University of Technology

Dept. of Child and Adolescent

Marktplatz 15

D-64283 Darmstadt

Psychiatry and Psychotherapy

University Hospital of Ulm

Germany

Steinhövelstr. 5

D-89075 Ulm - Germany 


\section{Introduction}

Children are therapeutic orphans and an underprivileged group in innovations derived from drug-therapy. Although the last few years have seen an expansion of child-related research on psychotropic medications subsequent to recent legislative incentives to industry (Riddle et al. 2001, Vitiello et al. 2004), research and development (R\&D) has not brought about a sufficient availability of newly registered drugs. This market failure has to do with enormous $R \& D$ costs and potential sunk costs. The innovation process of pharmaceuticals is a long, risky and very costly business (see Grabowski, 2003a, for a recent survey). As the size of the market determines the amount of sales, economists typically emphasise profit (i.e. sales minus costs) incentives and the size of the market as major driving forces of innovative activity. Thus, as children have a much lower probability of being a customer of pharmaceutical products, market incentives to produce drugs for children and juveniles are rather small.

In such markets, patent protection and market exclusivity seem to be promising avenues for spurring the innovation process. Indeed, the U.S. 1983 Orphan Drug Act (ODA) provides an interesting and successful experience worth being considered and adapted as a solution to obstacles to the European and German innovation process. ODA covers drugs which treat diseases affecting only a small number of people (less than 200,000 in the US, which is equivalent to about 7.5 patients / 10,000 inhabitants). The Act is based on economic incentives (tax credits, seven-year grant of market exclusivity and federal funding).The European Union followed the US example by launching the European Agency for the Evaluation of Medical Products (EMEA), which is responsible for approvals of pharmaceutical innovations in the European Union. In Germany, European directives are presently in the process of being implemented as part of national law. Here, introduction of European law has led to the $12^{\text {th }}$ amendment of the German Drug Code (German acronym AMG). However, as implementation of European law would require a more utilitarian 
view on clinical trials and innovation of new drugs (i.e. actions are to be judged on the basis of how their outcomes affect the general utility of society, even when some individuals might be worse off), medical professionals are rather pessimistic about any practical help from the latest amendment because of ethical concerns.

Thus, economic incentives, legal restrictions and ethical concerns seem to be responsible for the lack of innovative activity targeted at drugs for children, though social cost-benefit considerations (i.e. welfare analysis) would most probably predict a high gain from the introduction of critical innovations. Grounded on the highly interdisciplinary interplay between medical, pharmaceutical, psychopharmaceutical, psychotherapeutic and economic research as well as ethical restrictions, this survey aims at analysing channels of influence that might be helpful both in the analysis of the innovation process of drugs for children, and in improving the uncertain situation of pediatric therapy. We are going to highlight the influence of public policy, legal restrictions, enrolment of children in clinical trials, role of parents and doctors, as well as possibilities and limits of patent designs. Moreover, as pharmaceutical innovations touch on the current discussion on chances and risks of the biotech revolution, there is an ongoing feedback from innovative activity to society, and both public discussion on and attitudes towards topics such as off-label medication will in turn have a sustainable effect on future legal restrictions and, thus, on future innovations. Our survey will be guided by this reflexive view of the modernisation and innovation process.

This paper, written by an economist and two researchers from medical science, intends to give an interdisciplinary survey of the problem. We start by presenting some remarks on modern innovation processes from the general viewpoint of social sciences. We then inform about the innovative process in medical and pharmaceutical sciences under consideration of medical science, economic incentives and disincentives, as well as legal and ethical restrictions. 


\section{Innovations in the Post-Schumpeterian World of Reflexive}

\section{Modernisation.}

The German Ministry for Education and Research designated the year 2001 the year of "life sciences" and sought to support "verantwortbare Innovationspotenziale" (Bundesministerium für Bildung und Forschung (o. J.): Aktionsprogramm Lebenswissenschaften). ${ }^{1}$ The German Chancellor Gerhard Schröder has declared 2004 to be the "Jahr der Innovationen", i.e. the year of innovations.

These examples show that "innovation" has become a common expression, especially in political parlance, revealing the urgent need of (German) society to keep pace with recent technical, social and economic changes. Although politicians are rather unspecific and fuzzy in their terminology, there is a common sense that spurring innovative activity has become one of the uppermost goals of modern societies.

However, the situation has become more complex than it was before, as can be seen from the example of the achievements of the pharmaceutical industry in general, and from the limits to innovative progress set by economic market failure and by ethical concerns in the case of therapeutic innovations for children in particular. Whereas innovative activity primarily arose in a process well described as "creative destruction" by Schumpeter in his work "Capitalism, Socialism and Democracy" (1943), grounded on the idea that brilliant individuals (risk-taking entrepreneurs and inventors) such as Werner von Siemens or Alexander Graham Bell are the driving force of technical progress, we nowadays face a "post- Schumpeterian" paradigm (Rammert, 1997a), where neither single entrepreneurs nor public R\&D institutions (universities, MaxPlanck-Institutes, etc.) have the capabilities to succeed in a single-handed effort.

\footnotetext{
${ }^{1}$ See http://www.bmbf.de/pub/0330leb.pdf
} 
Instead, powerful and heterogeneous networks are needed to solve complex problems that simultaneously touch on scientific, social, economic, legal, environmental and ethical problems (see Rammert 1997b, 1999). Rammert (1999) presents an example of an innovation in medical science (related to Alzheimer disease), where 34 authors from bio-technical firms, pharmaceutical multinationals, a top university, a public research institution and a private nonprofit research lab were involved.

Thus, unlike the Schumpeterian world which was based on the idea that inventions were developed and brought to market in a straightforward and "linear" way, innovations in the $21^{\text {st }}$ century often suffer from the risks of ambivalent and unexpected side effects (i.e. negative external effects in terms of economics) which touch on the interests of third groups and require co-operation in many fields, and acceptance or at least toleration from other key players such as government, political parties, trade unions, church, civic action groups, ethics commissions etc. Thus, innovations in modern societies and resulting risks need to be considered in the way they impact on social innovations (see Areger 1976) and in particular in the context of "reflexive modernisation" ("reflexive Modernisierung") in the sense of Beck (see Beck 1986, Part 3, and Beck et al, 1996). We can conclude, as van de Ven (1988) has put it, "innovation [...] is a network effort", ( p. 115), and "[...] a collective achievement" (p. 105). ${ }^{2}$ This process is better described as one of back-and-forth or even as a zigzag walk which eventually leads to a final innovative outcome that might look very different from first preliminary ideas.

The climate described above very well fits the situation of the health sector, the pharmaceutical industry and in particular the field of research affecting minors. The health sector constitutes a typical sector in need of changes and innovation with paramount importance for society in terms of long-term and short-term

\footnotetext{
${ }^{2}$ Quoted in Gillwald (2000).
} 
consequences (see, for instance, Wichert 2003). On the one hand, innovations in the medical and health sector occur at a rapid rate, partly with paradigm changes in quick succession that, in turn, have an effect on further research. Here, the advances of the biotech revolution seem to open new horizons of scientific research. This system is, on the other hand, particularly susceptible to disturbances that hamper or prevent innovation (see also the discussion in Rogler \& Schölmerich 2000, Raspe 2001). ${ }^{3}$ Overcoming the limits to innovation requires knowledge of the interplay between innovation and its acceptance in society, because societal attitudes (in particular with respect to ambivalent and unexpected results) will feed back to innovative activities.

\section{The Market for Pharmaceuticals, Patents, and Market Failure for}

\section{Innovations Targeted at Children}

There are profound economic reasons that prevent innovations, even when they might be highly beneficial from a social cost-benefit point of view. In a manner well-suited to the creation of innovations in the field of "trial-and-error" research of pharmaceutics, Schumpeter (1911) described innovations ${ }^{4}$ as "new combinations" ("neue Kombinationen") that enable monopoly rents of pioneering entrepreneurs.

\footnotetext{
${ }^{3}$ Researchers such as the Vice President of the German Research Foundation (Deutsche Forschungsgemeinschaft, DFG), Jörg H. Hacker, point to the crucial importance of key technologies such as gene technology for future competitiveness of the German economy and warn against considering only the risks of innovations in this field: „Es stellt sich also die Frage: Ist Deutschland ein Land, das Innovationen auch auf dem Gebiet der Gentechnik will, oder werden einseitig die Risiken in den Mittelpunkt der Diskussion gerückt" (Hacker 2004, p.3)

${ }^{4}$ He does so without mentioning the word ,innovation“. It appears in his later publication on „Business Cycles“ (Schumpeter, 1939).
} 
Classical economic text books on industrial organisation such as that of Tirole $(1988)^{5}$ distinguish between product innovation and process innovation. Product innovations create new (or considerably improved) goods and services, whereas process innovations reduce the cost of producing by introducing new production techniques. Thus, our project on innovations in the field of orphan drugs for children deals with product innovations. Although process innovations are mostly seen as a matter of higher financial involvement, the picture is completely different in the case of pharmaceutical innovations. Darby and Zucker (2003) call progress in biotech research a "metamorphic" revolution rather than incremental progress that perfects existing products. Innovations are related to huge spending on research and development (R\&D) which amount to $\$ 800$ million on average for a single truly new drug (see below) and innovations are highly relevant because of their economic relevance as so called "drastic" innovations (see Tirole 1988, p. 391 for a formal definition) which allow appropriation of the social surplus of monopolistic markets. Due to their enormous expenditure on $\mathrm{R} \& \mathrm{D}$, their potentially huge (but uncertain) profits combined with their simultaneous "winner takes it all" risks (leading to patent races), pharmaceutical innovations are often referred to as "blockbuster innovations" (see Scherer 2002, among others).

Incentives to develop new pharmaceutical products and the regulation of the market by patent protection can be well understood using Schumpeter's (1943) classical work. Schumpeter's basic point is that monopoly situations and R\&D are intimately related. Monopolies are "natural breeding grounds" for R\&D, and if one wants to induce firms to undertake costly $R \& D$ as in the field of pharmaceuticals “... one must accept the creation of monopolies as a necessary evil" (Tirole 1988, p. 390). The presence of generics draws attention to the point

\footnotetext{
${ }^{5}$ See, in particular, chapter 10 of Tirole's book on Research and Development and the Adoption of New Technologies.
} 
that innovations, when published, attain the status of a public good. ${ }^{6}$ Thus the creation of new pharmaceutical products is encouraged by a system of patents throughout the world. The dilemma of the patent system is that, in preventing immediate production of generic products which are less expensive to patients, it creates a non-competitive situation which might be different from that of a social welfare optimum. As a general rule, however, insights dating back to Nelson (1959) and Arrow (1962), according to which even partial imitation of discoveries may yield particularly low incentives to do $R \& D$, seem to characterise research policy and patent systems in the field of biomedical and pharmaceutical research. Pharmaceuticals crucially rely on patent protection, and changes to law and regulation would affect incentives to invest substantially.

On the supply side, the market for pharmaceuticals is highly international, leading to a rather low concentration rate. However, recent developments reveal increased merging and acquisition activities such as attempts at hostile takeover (see Aventis-Sanofi). A substantial share of market profits is achieved from generic producers who compete with R\&D-oriented, branded firms. Profit margins of branded firms are under pressure because generic products are now available only a few months after end of patent, and because generics are increasingly favoured by insurance coverage. ${ }^{7}$

Who demands pharmaceuticals? Demand is driven by the needs of patients and the knowledge of physicians. As the size of the market determines the amount of sales, economists typically emphasise profit (i.e. sales minus costs) incentives

\footnotetext{
${ }^{6}$ A public good is defined as non-rivalrous, i.e. it does not exhibit scarcity, and once it has been produced, everyone can benefit from it in a non-excludable way, meaning that it is impossible to prevent people from gaining access to the good.
}

${ }^{7}$ Grabowski (2003a) reports U.S. evidence, according to which for the 1994-79 cohort of brand name products, generic drugs captured a 64 percent market share after one year on the market. This increased to $73 \%$ after the second year. 
and the size of the market as major driving forces of innovative activity. Recent results by Kremer (2002) and Acemoglu and Linn (2003) on innovations in the pharmaceutical industry confirm classical arguments put forward by Schmookler (1966) according to which "the amount of invention is governed by the extent of the market".

Thus, as children have a much lower probability of being a customer of pharmaceutical products, market incentives to produce drugs for children and juveniles are rather small. ${ }^{8}$ Exceptions are vaccines (if applicable to all children) and some cough and cold medicines (see Meadows, 2003). Meadows (2003) reports US experience where experts see small financial benefits as the primary reason why there is a lack of pediatric drug testing.

The second reason might be even more important in Europe and Germany than in the U.S. It has to do with ethical issues that make it more difficult and costly to carry out studies on children. As will be described in more detail below, it is necessary to dispose of "child-friendly environments in any sense, from ageappropriate equipment and medical techniques to pediatric specialists who are sensitive to a child's fear" (quote D. Murphy, director of the U.S. Food and Drug Administration's (FDA) Office of Pediatric Therapeutics, Meadows 2003). Because highly elaborated ethical procedures have to be administered, the problems associated with "informed consent" to participate in a clinical trial would, from a pure company-specific cost-benefit point of view, drive up development costs (see below). As, on the other hand, market sizes are rather small, opportunity costs of developing new products for children are prohibitively high. Expected revenues from orphan drugs and neglected studies

\footnotetext{
${ }^{8}$ Moreover, the market of the younger generation is losing ground relative to the market of the older generation. Whereas the share of young people under 20 years of age was $30 \%$ in 1970 in Germany, it will go down to only $17.1 \%$ in 2030 . At the same time, the ratio of the population of more than 60 years of age will increase from $19.9 \%$ in 1970 to 34.4 in 2030 (Statistisches Bundesamt, cited by Frankfurter Allgemeine Sonntagszeitung, April $17^{\text {th }}, 2004$, p. 35).
} 
for children are too small to justify the high fixed and potentially sunk costs of pharmaceutical R\&D.

\section{Cost-Benefit Considerations and the Value of Medical Research}

As has been emphasised above, the unregulated market for drugs for children and for orphan drugs in general does not entail the market power necessary to create innovations. To protect intellectual property and to spur innovations, governments of most countries regulate the market by allowing ownership of monopoly right, i.e. patents, for a duration of 20 years. ${ }^{9}$ After 20 years the patent becomes free for use. To understand the social benefit net of costs from patents and development, some information on costs and benefits of producing pharmaceutical products is appropriate.

Research and development of pharmaceuticals is a long, risky and very costly business (see Grabowski, 2003a, for a recent survey). According to Di Masi et al. (2003), the average capitalised $R \& D$ cost for a truly new $\operatorname{drug}^{10}$ during the preclinical and clinical R\&D phases amount to $\$ 802$ million. Figures published by FDA (FDA 2004) even report costs ranging between $\$ 0.8$ and $\$ 1.7$ billion. Recent data suggest that the investment required to launch a new drug has risen 55 percent during the last five years (FDA 2004) ${ }^{11}$. One of the main reasons $\mathrm{R} \& \mathrm{D}$ is so costly is that most new drug candidates fail to reach the market. Typically, less than one percent of the compounds examined in the preclinical

\footnotetext{
${ }^{9}$ In Germany, average effective duration of patent protection is 8 years. Patents need to be registered in the very early stage of development, testing new drugs takes about 10 years and the process of formal approval by the patent office and the Bundesinstitut für Arzneimittel und Medizinprodukte, BfArM takes another two years (BPI 2003, p.59-60). Recent evidence for the US (Grabowski, 2003) reports that the cohort of new biopharmaceutical innovations in 2000-01 had a total clinical development time (i.e. without preclinical studies, but with FDA approval) of 86 months.

${ }^{10}$ This refers to submissions on new molecular entities (NMEs).

${ }^{11}$ See also the related article in „Frankfurter Allgemeine Sonntagszeitung“ dated March 27, 2004: „Was neue Pillen kosten“.
} 
period reach the phase of human testing, and only 20 percent of the compounds entering clinical trials gain FDA approval (Di Masi, 1995).

Despite such huge costs, patent protection leads to monopoly profits, provided market sizes are sufficiently large. Such returns on R\&D can be enormous though present values of net revenues exceed average R\&D costs only for the top three deciles of new drug introductions (see Grabowski, Vernon and Di Masi, forthcoming, and Grabowski 2003a). This once again confirms the inherent risk of new drug introductions which can be more easily covered by risk diversification (development of a portfolio of new drugs) by large multinational companies.

While private (company-specific) cost-benefit considerations of introducing new drugs might not have been a success in each single case despite patent protection, the benefits to society of new drugs are quite high and far exceed (mostly private) costs. There are at least three recent contributions to the literature underlining this result: Lichtenberg (2003b), providing new evidence and a survey of his own recent research on this topic (see, in particular, Lichtenberg 1996, 2003a), Nordhaus (2003) and Murphy and Topel (2003). Benefits arise from longevity increase ${ }^{12}$, improved quality of life, higher productivity (less working days lost, including those of close relatives), and reduced total medical expenditure. Focusing on the benefits of longevity as an example, Lichtenberg presents econometric evidence based on data from 19611997 indicating that the average new drug approval increases life expectancy of people born in the year in which the drug is approved by 0.016 years (5.8 days). Accumulating direct and indirect effects from later cohorts and taking account of the fact that there are 4 million births per year in the U.S., the average new drug approval increases the total expected life-years of current and future

\footnotetext{
12 Note that costs in the final two years of life are lower for people who live longer (Lichtenberg, 2003b, p. 46).
} 
cohorts by 1.2 million. Lichtenberg compares these benefits to the costs of bringing new products to the market which he estimates to be about $\$ 500$ million, leading to cost per life-year gained to be in the order of $\$ 424$ ( $\$ 500$ million/ 1.2 million life-years).

Opportunity costs of not disposing of new drugs require monetizing the value of better health and longer life. William Nordhaus (2003), along with Kevin Murphy and Robert Topel offered parallel estimates of the value of recent increases of longevity. ${ }^{13}$ Murphy and Topel (2003) estimate the economic value of a life-year on the order of $\$ 150,000$, rendering costs of $\$ 424$ per life-year estimated by Lichtenberg (2003b) only a small fraction of social benefits. Murphy and Topel (2003) estimate the total value of increased longevity to entire U.S. population to be \$57 trillion over the period 1975 to 1995.

Lichtenberg (2003b) reports further efforts to estimate benefits from quality of life and from reduced medical expenditures, and he also presents case studies of orphan diseases. Summing up, social gains from new pharmaceuticals are quite high and exceed costs. High welfare benefits seem to suggest that the public sector could do much more to subsidise R\&D of drugs, in particular orphan drugs and drugs for children. The problem is that welfare gains such as those stemming from longevity are intangible gains such that other incentives and regulatory solutions need to be found for practical policy purposes.

\footnotetext{
${ }^{13}$ It may scarcely seem possible or even morally offensive to put monetary values on human life. But modern econometrics has devised a credible method based on compensating wage differentials for people changing to a job with a higher risk of death. This technique is based on the observation that people have to be "bribed" in everyday settings to incur small but predictable increases in the risk of death. Extrapolation of both risks and compensations obtained for taking higher risks leads to estimated values of statistical lives. Related to this, see also the interview with Professor Martin Hellwig (Frankfurter Allgemeine Sonntagszeitung, August $\left.24^{\text {th }}, 2004\right)$. On being asked whether death could be subject to costbenefit considerations, he answered: „Das tut jeder, der vor einem heranfahrenden Auto über die Straße geht, auch jeder der zur Polizei oder zur Feuerwehr geht, statt in einem Büro zu arbeiten". Most estimates for the value of a statistical life are within the relatively narrow $\$ 3$ million to $\$ 7$ million range.
} 


\section{Innovation in Child and Adolescent Psychiatry - Medical-Scientific}

Approach to Pharmacologic R\&D for Minors

Considerations of the last section represent incentives and obstacles of the economic approach to research activities for minors. Medical science and the community of physicians, however, discuss somewhat deviating desiderations and other intentions for $R \& D$ in pediatrics and in child and adolescent psychiatry. According to the image medical science has of itself, not only financial aspects promote research, and not only research fit for markets has been developed (see below). In the international community of researchers into psycho-pharmacology needs for $R \& D$ are clarified, without the economic environment becoming substantially changed. During the 1990s, it became more common to use pharmacological interventions to treat children with a variety of psychiatric disorders, although incentive programs for research and licensing of drugs for minors began later or just at this time (Zito et al 1999, Olfson et al. 2002). It seems that it was not only or not primarily economic (more precisely, financial) aspects that pushed treatment options and research into drugs for minors.

As Shirkey and Rylance recognized in the 1960ies and 1970ies, children are therapeutic orphans and an underprivileged group in drug-therapy (Shirkey 1968, Rylance 1979). With a delay of about one generation a general change of attitude in the scientific community towards research on medication for children is now taking place (Thiele, Rheinberger 2003). The last few years have seen a major expansion of child-related research on psychotropic medications subsequent to increasing use of psychotropic medications in children and recent legislative incentives to industry (Riddle et al. 2001, Vitiello et al. 2004). In the rapidly changing context of pharmacological research, the interface between publicly and privately funded research needs to be reconsidered in order to integrate activities and avoid unnecessary duplication of efforts. Once, by 
default, the almost exclusive domain of public research, child research is now increasingly funded by industry (Vitiello et al. 2004).

The phenomenon of increasing pharmacological research and treatment has not brought about a sufficient availability of registered drugs. In contrast, the increasing off-label use of psychotropics in children, coupled with the lack of adequate data to support their efficacy and safety, was eventually recognized as an important public health issue to be addressed through research in both the U.S. (Vitiello \& Jensen, 1997; Jensen et al. 1999) and Europe (Fegert 2003). In spite of the orphan drug regulations in Europe since 2001 until now (see below), 51 drugs or application modifications have been licensed. Only two substances for psychiatric disorders are among these products, whereas the majority of drugs concern treatments for allergic diseases, vaccinations and application modifications (VFA 19.2.2004). ${ }^{14}$ By contrast, in the list of FDA indicating the further research required for minors, 21 substances for neurological or psychiatric disorders are itemized (FDA v. 2002).

\section{Legal and Ethical Restrictions for Scientific Medical Research}

\subsection{International Experiences of Legal Regulations on $R \& D$ of Pharmaceuticals for Children}

The innovation of drugs is protected by patent law. Without such governmental regulations market failure would have prevented expensive and risky R\&D on pharmaceuticals. While market size seems to be sufficiently large in particular for drugs of the elder generation, market failure seems to be still dominant for orphan diseases and third world diseases like malaria.

\footnotetext{
${ }^{14}$ In detail, in 200114 substances/application modifications (s/am) were licensed, in 200222 s/am, in $200313 \mathrm{~s} / \mathrm{am}$, in $20042 \mathrm{~s} / \mathrm{am}$. VFA: Europäische Zulassungen und Zulassungserweiterungen für Arzneimittel oder Applikationshilfen, 19.2.2004
} 
The U.S. 1983 Orphan Drug Act (ODA) provides an interesting experience worth being considered and extended as a solution to European and German problems. ODA covers drugs which treat diseases affecting a small number of people (less than 200,000 in the US, which is equivalent to about 7.5 patients / 10,000 inhabitants). ${ }^{15}$ The Act is based on the economic incentives described above. ${ }^{16}$ Of the three primary incentives incorporated in the Act, the seven-year grant of market exclusivity ${ }^{17}$ is considered the most significant by the drug industry (see corresponding statements in, for instance, Rohde, 2000, or Meadows, 2003). Indeed, the annual average number of drugs for rare diseases brought to market during 1983-1999 was twelve times as great as it was during 1973-1982 (Lichtenberg 2003b, p.47).

To avoid the problem of off-label use and to spur R\&D of drugs for pediatric use, even greater and particular efforts were needed. The FDA tried to follow a carrot-and-stick policy. While the "carrot" is given by the market exclusivity described above, the "stick" was represented by the so called "pediatric rule". The FDA tried to require pediatric studies of a new drug submitted for approval if the product was likely to be used for pediatric patients. The idea was to avoid off-label use, that is, children should have access to drugs properly tested for pediatric use. However, the pediatric rule, added to the existing legislation of ODA in 1997, failed to be relevant in reality. It was criticised because of the

\footnotetext{
${ }^{15}$ See, among others, Rohde (2000), Kleist (2001), Stürchler (2002), Meadows (2003), Grabowski (2003b). See also file: http://www.orphaneurope.com/orphan druglegislations.html

${ }^{16}$ It is based on three primary incentives: 1) $50 \%$ tax credit for R\&D expenses incurred in clinical trials, 2) federal funding of grants and contracts for clinical trials of orphan products, and 3) grant of an exclusive right to market the orphan drug for seven years from the date of FDA approval

${ }^{17}$ Note that "market exclusivity" goes beyond (and probably extends) patent protection. The main advantage is that monopoly rights can be protected against imitators and competitors in a more effective way than with patents (see Stürchler, 2002).
} 
missing legal authority of the FDA to require pediatric rules and finally overturned by the federal court in 2002 (Meadows 2003).

In June 1998, existing legislation of ODA was refined when the U.S. Congress passed the Food and Drug Administration Modernization Act which provided financial incentive to the pharmaceutical industry in return for conducting pediatric research, and legislation was then further expanded and extended until 2007, with the Best Pharmaceuticals for Children Act (U.S. Congress 2002). The additional incentive (i.e., a 6-month extension in the drug patent exclusivity) has substantially changed the approach of industry to pediatric pharmacology, also including pediatric psychopharmacology. As of January 31, 2004, pediatric studies had been requested by the Food and Drug Administration (FDA) for a total of 283 drugs, of which 36 (13\%) were neuropharmacological medications (FDA 2003a). As of February 25, 2004, the 6-month additional exclusivity for pediatric studies had been granted by FDA for 94 drugs, 10 (11\%) of which were neuropharmacological medications (FDA 2003b). Although many of these studies are rather small pharmacokinetic and doseranging investigations, insufficient per se to support pediatric indications, their number attests to the new vitality of the field. The recently passed Pediatric Research Equity Act of 2003 (U.S. Congress 2003), which provides FDA with the authority to request industry to conduct pediatric studies even before drugs are approved for marketing, is likely to further spur child research.

Other countries followed the US example. Japan introduced the Orphan Drug Legislation in 1993, Australia started its Orphan Drug Program in 1998. The European Union followed the U.S. example by launching the European Agency 
for the Evaluation of Medical Products (EMEA), which is responsible for approvals in the European Union. ${ }^{18}$

At present, European directives are in the process of being implemented as part of national law. In this context international guidelines on Good Clinical Practice (GCP) are going to be valid for the USA, Japan and Europe. The GCP guideline is currently being implemented via EU directive 2001/20 into European national law. GCP is considered as the central guideline applicable to research projects as "an international ethical and scientific quality standard for designing, conducting, recording, and reporting trials that involve human subjects. Compliance with GCP assures that the rights, safety, and well-being of trial subjects are protected and that the clinical trial data are credible."19 (Federal Register Vol.62, No.90, May 9, 1997, pp. 25691-25709)

In Germany, implementation of European law has led to the $12^{\text {th }}$ Amendment of the German Drug Code (German acronym AMG), and is the subject of discussion as draft legislation in the corresponding committees. ${ }^{20}$ Experts see the effects of the implementation of the GCP guideline in a rather critical light: higher regulatory requirements might cause a decline in the number of clinical studies, and industry-funded research may hardly be performed in future. ${ }^{21}$

\footnotetext{
${ }^{18}$ In the EU, orphan diseases are defined by applying a prevalence rate of 5/10,000. EMEA has extended market exclusivity for the duration of 10 years, but it can reduce this period to a limited duration of 6 years if profits are sufficiently high.

19 About the international validity of GCP: "This International Conference on Harmonization (ICH) guidance provides a unified standard for the European Union, Japan, and the United States to facilitate the mutual acceptance of clinical data by the regulatory authorities in those jurisdictions."

${ }^{20}$ The planned date for implementation (May 2004) will not be met, not only in Germany.

${ }^{21}$ This topic was discussed at an international conference in Munich 2004: EU Clinical Trial Directive, Regulators' Interpretation and Implementation Advice, $26^{\text {th }}$ Feb 2004. The lecture of B. Hart, Director of Clinical Science, AstraZeneca, UK, especially, mentioned the loss of competitiveness of Western Europe as Trial Center.
} 
Thus, national programs similar to those launched by the US government have not yet been implemented in Europe. It is an open question whether European or German law would lead to a decision similar to patent exclusivity.

\subsection{Ethical Concerns}

Moreover, there are strong rules for protection scope aimed in particular at groups and persons who are not able to give consent (Buchanan, Brock 1989, McCormick 1989, Levine 1986, p. 236, Arras \& Rhoden 1989). Remembering the inhumane experiments of National Socialist researchers in concentration camps, especially dependent persons such as minors, mentally disabled and psychiatric patients are understood as such people or groups (Dahl, Wiesemann 2001; Bücheler et al. 2002; Thiele, Rheinberger 2003; Weiss Roberts \& Roberts 1999; Vollmann 2000). However, in legal regulations applicable to date the inability of minors to give consent was generally assumed and was neither questioned nor the subject of scientific research (Graham 1991, p. 355, Rothärmel et al. 1999, Robinson 2001, Fundudis 2003, Kölch 2003).

In Germany, due to various reasons, a rather restrictive legislation is to be assumed, characterized by the idea of putting the protection of the individual human being before the collective interests. There is a climate of utmost reluctance in Germany towards medical trials on persons who are not able to give their consent and also a rather reluctant attitude towards relaxation of strict regulations that aim primarily at the protection of the individual.

The $12^{\text {th }}$ Amendment of the German Drug Code ("12. Novelle zum Arzneimittelgesetz", May 2004), has brought new elements to the debate. The importance of general (aggregate) utility ("Gruppennutzen") has for the first time been acknowledged and mentioned in an explicit way. In accordance with Bentham's (1748 - 1832) utilitarianism, actions are to be judged strictly on the basis of how their outcomes affect the general utility (aggregate utility) of 
society, implying a stronger focus on the utilitarian view of clinical trials and development of new drugs. Thus, economic cost-benefit considerations which most probably would predict a high social surplus from $R \& D$ of drugs for minors would have to be seen in a different light. However, as such social gains are mostly intangible - unless insurance companies are involved - and because individual human rights have utmost priority, it is unclear what pointing to aggregate utility will mean in legal and medical practice.

\section{Organisation of Research Networks: Institutional Aspects}

Medical research today is performed in academic research at universities and public/national research institutes, in research institutions financed by the pharmaceutical industry and by foundations. There is interaction among these sectors: Industry supports pediatric psychopharmacology research through investigator-initiated grants and by giving unrestricted grants to academic sites. Unrestricted grants are an extremely valuable source of funding for academic child research as they are typically utilized to fund add-on projects to existing studies, train junior investigators, or conduct innovative pilot studies, often in less prevalent disorders, such as autism or Tourette's disorder (Sallee et al. 2000).

R\&D of new drugs is the domain of industry-sponsored research. However, there are fundamental differences between the US and Europe: In the U.S., a substantial share of research is governmentally funded, and, as is the case with the NIMH, researchers possess a powerful research institution which is urged to investigate psychiatric diseases and which has its own department dealing with child and adolescence-related issues (NIMH Child and Adolescent Treatment and Preventive Intervention Research Branch). Furthermore, in the USA public 
funding for research in pediatric psychopharmacology has grown substantially. ${ }^{22}$ There is no equivalent European institution with similar influence and research budget (Vitiello et al. 2004). In particular, NIMH supports research projects which are of no interest for industry because of lacking market sizes, but which are needed for minors, for instance by projects on the relative efficacy of pharmacotherapy combined with psychosocial interventions, or with combined use of pharmacotherapy and psychosocial interventions. ${ }^{23}$ As a result, testing clinically important questions with adequate statistical power and thus arriving at definitive conclusions about the treatment efficacy is possible.

The public funding of research in minors has great importance because industrysponsored research has limitations. Vitiello et al. emphasize the problematic lack of freedom of information (Vitiello et al. 2004): the exclusive property rights of sponsors to databases of industry-sponsored studies often make it difficult or impossible for academic researchers to have direct access to the entire research data collected in multi-site clinical trials. In general, these databases cannot be accessed through the U.S. Freedom of Information Act. There are no guarantees that research findings will be published if they are not of interest to industry. ${ }^{24}$ Recent difficulties in addressing concerns about a possible link between SSRI antidepressant use and suicidal behavior in youths can be in part ascribed to the lack of standardized and sensitive methods for safety ascertainment (FDA 2004, Fegert 2004).

\footnotetext{
${ }^{22}$ By NIMH the extramural intervention research funding in children from 1997 to 2003 for pediatric psychopharmacology increases more than three times about to $\$ 39$ million. (Vitiello et al. 2004)

${ }^{23}$ These trials are often conducted under cooperative agreements or contracts, which are collaborative efforts between academic investigators and NIMH researchers (Lebowitz et al 2003)

${ }^{24}$ For drugs for which the FDA approves an indication, the data and information provided to the FDA advisory committee can be released to the public. However, data from studies that do not lead to marketing approval of an indication or other label changes cannot be accessed without industry permission. (Vitiello et al. 2004)
} 
Industry-funded studies are less likely to be published than other studies (Lexchin et al. 2003) and are more likely to report conclusions favorable to their product (Melander et al. 2003; Als-Nielsen et al 2003). This bias adds to the fact that journals have been reluctant to publish data from studies that fail to detect treatment effects. On completion of a multi-site trial, investigators are typically given a copy of the data collected at their site, but not the entire study database (Pharmaceutical Research and Manufacturers of America 2002). Secondary data analyses cannot be conducted independently by the investigators.

Vitiello et al. carried out domains for research where non-industry-initiated studies are requested (Vitiello et al. 2004): these are questions without the promise of profit, but are of high interest for physicians and minors. Examples are given by research into the efficacy and safety of combined treatments, either psycho-pharmacon in combination with psychotherapy or psycho-social interventions or the combination of two or more medications for the purposes of augmenting therapeutic effects. Trials on efficacy and safety of interventions for treatment-resistant children and the long-term effects of medication are necessary, as are trials on the impact of treatment on distal outcomes, prognosis of illness and level of functioning; treatment development and testing in less common conditions for orphan drugs; search for moderators of treatment response, which can lead to the identification of patient subtypes most sensitive to the effects (positive and negative) of medications; studying the effect of medications on development; etc.

\section{Conclusions}

Lack of economic incentives, legal restrictions and ethical concerns seem to be responsible for the absence of innovative activity targeted at drugs for children, though social cost-benefit considerations (i.e. welfare analysis) would most probably predict a high gain from the introduction of critical innovations. This 
interdisciplinary survey informs about the highly complicated innovation process, which, on the one hand touches on the current discussion on chances and risks of the biotech revolution, and which is affected by the public discussion and attitude on topics such as off-label medication and clinical tests on children on the other hand. The focus is on the evaluation of specific pathways towards successful (or less successful) innovative outcomes. Among others, the influence of public policy, legal restrictions, enrolment of children in clinical trials, role of parents and doctors, as well as possibilities and limits of patent designs are discussed. Cooperation of academic research at universities and public/national research institutes, and research institutions financed by the pharmaceutical industry and by foundations is seen as an important source of future progress.

\section{References}

Acemoglu, D., Linn, J. (2003): Market Size in Innovation: Theory and Evidence from the Pharmaceutical Industry, mimeo, MIT, Dept. of Economics.

Als-Nielsen, B., Chen, W., Gluud, C., Kjaergard, L. L. (2003): Association of funding and conclusions in randomized drug trials. JAMA 290:921-928.

Aregger, K. (1976). Innovation in sozialen Systemen. (2 Bd.).Bern.

Arras, J.; Rhoden, N. (ed.)(1989): Ethical Issues in Modern Medicine. 3. issue. Mountain View.

Arrow, K. (1962): Economic Welfare and the Allocation of Resources for Inventions, in: R. Nelson (Ed.), The Rate and Direction of Inventive Activity, Princeton University Press.

Beck, U. (1986): Risikogesellschaft. Auf dem Weg in eine andere Moderne, darin: Dritter Teil: Reflexive Modernisierung: Zur Generalisierung von Wissenschaft und Politik, S. 279-374, Frankfurt a.M.

Beck, U., A. Giddens, S. Lash (1996), Reflexive Modernisierung. Eine Kontroverse, Frankfurt a. M.

BPI (2003), Pharma-Daten 2003, Bundesverband der Pharmazeutischen Industrie, http://www.bpi.de/internet/download/pharmadaten_2003.pdf (April 25, 2004). 
Bücheler, R.; Schwab, M.; Mörike, K.; Kalchthaler, B.; Mohr, H.; Schröder, H.; Schwoerer, P., Gleiter, C. H. (2002): „Off-label prescribing to children in primary care in Germany: retrospective cohort study“. BMJ 324, pp. 13111312.

Dahl, M.; Wiesemann, C. (2001): „Forschung an Minderjährigen im internationalen Vergleich: Bilanz und Zukunftsperspektiven“. Ethik Med. 13 , p. $87-110$.

Darby, M. R., Zucker, L.G. (2003), Growing by Leaps and Inches:Creative Destruction, Real Cost Reduction, and Inching Up, in: J.V. Duca and M.K. Yücel (eds.), Science \& Cents: Exploring the Economics of Biotechnology, Federal Reserve Bank of Dallas, 13-42.

DiMasi, J.A. (1995): Success Rates for New Drugs Entering Clinical Testing in the United States, Clinical Pharmacology and Therapeutics, 58, 1-14.

DiMasi, J.A., Hansen, R.W. , Grabowski, H.G. (2003): The Price of innovation: New Estimates of Drug Development Costs, Journal of Heath Economics, 22, 151-185.

European Parliament (2000): Regulation on Orphan Medicinal Products. Regulation N0. 141/2000. Official Journal of the European Communities. January 22, 2000. Available at:

http://pharmacos.eudra.org/F2/orphanmp/index.htm. (Accessibility verified March 8, 2004).

Fegert, J. M., Rothärmel, S. (2000): Psychisch kranke Kinder und Jugendliche als Waisenkinder des Wirtschaftlichkeitsgebots? Praxis der Kinderpsychologie und Kinderpsychiatrie. Sonderdruck 2:127-132.

Fegert, J. M. (2003): Entwicklungspsychopharmakologie: Terra incognita oder Forschungswüste? Nervenheilkunde 2/03:3-5.

Fegert, J. M. (2004): Depressionsbehandlung mit SSRI in der Kinder- und Jugendpsychiatrie - Ein Forschungs- oder ein Informationsdebakel? Nervenheilkunde 23: 60-64.

Food and Drug Administration (2004): Psychopharmacologic Drugs Advisory Committee and the Anti-Infective Drugs Advisory Committee. February 2, 2004. Briefing Information. Available at:

http://www.fda.gov/ohrms/dockets/ac/04/briefing/4006b1.htm (access verified March 8, 2004).

Food and Drug Administration (2003a): Approved moieties to which FDA has issued a written request for pediatric studies under section 505A of the Federal Food, Drug, and Cosmetic Act. Available at: http://www.fda.gov/cder/pediatric/wrstats.htm (Last updated January 31, 2004; accessibility verified March 8, 2004). 
Food and Drug Administration (2003b): Approved moieties to which FDA has grated pediatric exclusivity for pediatric studies under section 505A of the Federal Food, Drug, and Cosmetic Act. Available at:

http://www.fda.gov/cder/pediatric/exgrant.htm (Last updated: February 25, 2004; accessibility verified March 8, 2004).

Food and Drug Administration (2003c): FDA Public Health Advisory: Reports of Suicidality in Pediatric Patients Being Treated with Antidepressant Medications for Major Depressive Disorder (MDD). October 27, 2003. Available at: http://www.fda.gov/cder/drug/advisory/mdd.htm; accessibility verified March 8, 2004).

Fundudis, T. (2003): Consent issues in Medico-Legal Procedures: How Competent Are Children to Make Their Own Decisions? Child Adolescent Mental Health 8:1, 18-22.

Gillwald, K. (2000): Konzepte sozialer Innovation, WZB Discussion Paper P00-519, Berlin.

Grabowski, H.G. (2003a): Patents and New Product Development in the Pharmaceutical and Biotechnology Industries, in: J.V. Duca and M.K. Yücel (eds.), Science \& Cents: Exploring the Economics of Biotechnology, Federal Reserve Bank of Dallas, 87-104.

Grabowski, H.G. (2003b), Innovation and R\&D Incentives for Orphan Drugs and Neglected Diseases, Duke University, http://www.earthinstitute.columbia.edu/cgsd/documents/grabowski.ppt (April 26 $6^{\text {th }}, 2004$ ).

Grabowski, H.G., Vernon, J., DiMasi, J. (forthcoming), Returns on R\&D for New Drug Introductions in the 1990s, PharmacoEconomics.

Graham, Ph. (1991): Ethics and Child Psychiatry, in: Bloch, Chodoff. pp. 341363.

Hart, B. (2004): Industry View: Working with Vulnerable Groups at AtsraZEneca, lecture on EU Clinical Trial Directive, Regulators' Interpretation and Implementation Advice. Munich 26th Feb 2004.

Jensen, P. S., Bhatara, V. S., Vitiello, B., Hoagwood, K., Feil, M., Burke, L. B. (1999): Psychoactive medication prescribing practices for U.S. children: gaps between research and clinical practice. J Am Acad Child Adolesc Psychiatry 38:557-565.

Kleist, P. (2001): Immer noch Waisenkinder der Medizin, Politik, Ökonomie und Recht, 2221-2229.

Kölch, M. (2003): Aufklärung bei Kindern in klinischen Studien. In:

Wiesemann, Dörries (Hg.): Das Kind als Patient. Frankfurt a. M. 2003. 
Kremer, M. (2002): Pharmaceuticals and the Developing World, Journal of Economic Perspectives, 16(4), 67-90

Lebowitz, B. D., Vitiello, B., Norquist, G. S. (2003): Approaches to multisite clinical trials: the National Institute of Mental Health perspective. Schizophrenia Bull 29:7-13.

Levine, R. J. (1986): Ethics and Regulation of Clinical Research. 2. issuel., Baltimore a.o.

Lexchin, J., Bero, L. A, Djulbegovic, B., Clark, O. (2003): Pharmaceutical industry sponsorship and research outcome and quality: systematic review. BMJ 326:1-10.

Lichtenberg, F. R. (1996): Do (More and Better) Drugs Keep People Out of Hospitals?, American Economic Review, 86, 384-388.

Lichtenberg, F. R. (2003a): Pharmaceutical Innovation, Mortality Reduction, and Economic Growth, in: in: K. M. Murphy and R. H. Topel (eds.), Measuring the Gains from Medical Research. An Economic Approach, Chicago: University of Chicago Press, 74-109.

Lichtenberg, F. R. (2003b): The benefits to society of new drugs: A survey of the econometric evidence, in: J.V. Duca and M.K. Yücel (eds.), Science \& Cents: Exploring the Economics of Biotechnology, Federal Reserve Bank of Dallas, 43-59.

McCormick, R. A. (1989): Proxy Consent in the Experimentation Situation, in: Arras, Rhoden., pp. 460-471.

Meadows, M. (2003): Drug Research and Children, FDA Consumer magazine, http://www.fda.gov/fdac/features/2003/103_drugs.html .

Melander, H., Ahlqvist-Rastad, J., Meijer, G., Beermann, B. (2003): Evidence $\mathrm{b}(\mathrm{i})$ ased medicine - selective reporting from studies sponsored by pharmaceutical industry: review of studies in new drug applications. BMJ 326:1171-1173.

Murphy, K. M. and Topel, R. (2003): The economic value of medical research. In: K. M. Murphy and R. H. Topel (Eds.), Measuring the Gains from Medical Research. An Economic Approach, Chicago: University of Chicago Press, 41-73.

Nelson, R. (1959): The Simple Economics of Basic Research, Journal of Political Economy, 67, 297-306.

Nordhaus, W. (2003): The health of nations: The contribution of improved health to living standards. In: K. M. Murphy and R. H. Topel (eds.), Measuring the Gains from Medical Research. An Economic Approach, Chicago: University of Chicago Press, 9-40. 
Olfson, M., Marcus, S. C., Weissman, M. M., Jensen, P. S. (2002): National trends in the use of psychotropic medications by children. J Am Acad Child Adolesc Psychiatry 41:514-521.

Rammert, W. (1997a): Auf dem Weg zu einer post-schumpeterianischen Innovationsweise: Institutionelle Differenzierung, reflexive Modernisierung und interaktive Vernetzung im Bereich der Technikentwicklung. In: D. Bieber (Hrsg.), Technikentwicklung und industrielle Arbeit. Frankfurt a. M.

Rammert, W. (1997b): Innovation im Netz. Neue Zeiten für technische Innovationen: heterogen verteilt und interaktiv vernetzt. Soziale Welt 48, S. 397-416.

Rammert, W. (1999): Wer ist der Motor der technischen Entwicklung heute? Von der innovativen Persönlichkeit zum Innovationsnetzwerk. In: R. Boch (Hrsg.), Patentschutz und Innovation in Geschichte und Gegenwart. Frankfurt a. M., S. 183-200.

Raspe, R. (2001): Die Heilkunde wird eine Wissenschaft sein, oder sie wird nicht sein" - Anmerkungen zur evidenzbasierten Medizin und ihrer Kritik durch Rogler und Schölmerich. ZaeFQ 95: 495-501

Riddle, M. A., Kastelic, E. A., Frosch, E. (2001): Pediatric psychopharmacology. J Child Psychol Psychiatry. 42:73-90.

Robinson, S. (2001): Informed consent in children, GCP Journal 8: 8, 1-2.

Rogler, G., Schölmerich, J. (2000): "Evidence-biased-Medicine" - oder die trügerische Sicherheit der Evidenz. DMW 38: 1122-1128.

Rohde, D.D. (2000): The Orphan Drug Act: An Engine of Innovation? At What Cost?, Food and Dug Law Journal, 55, 125-143.

Rothärmel, S., Wolfslast, G. and Fegert, J. M. (1999): Informed Consent, ein kinderfeindliches Konzept? MedR (7):293-298.

Rylance, G. (1979): The therapeutic underprivileged. Dev Med Child Neurol. 21: 399-400.

Sallee, F. R., Kurlan, R., Goetz, C.G., Singer, H., Scahill, L., Law, G., et al. (2000): Ziprasidone treatment of children and adolescents with Tourette's syndrome: A pilot study. J Am Acad Child Adolesc Psychiatry 39:292-299.

Scherer, F.M. (2002), A Note on Global Welfare in Pharmaceutical Patenting, Federal Reserve Bank of Philadelphia, Working Paper 03-11.

Schmookler, J. (1966), Invention and Economic Growth, Harvard University Press.

Schumpeter, J. A. (1911): Theorie der wirtschaftlichen Entwicklung. Eine Untersuchung über Unternehmergewinn, Kapital, Kredit, Zins und den Konjunkturzyklus, Berlin: Duncker \& Humblot. 
Schumpeter, J. A. (1939): Konjunkturzyklen. Eine theoretische, historische und statistische Analyse des kapitalistischen Prozesses. 2 Bde. Göttingen: Vandenhoeck \& Ruprecht.

Schumpeter, J. (1943), Capitalism, Socialism and Democracy, London: Unwin University Books.

Shirkey, H. (1968): Therapeutic orphans. J. Pediatr; 72: 119-120.

Stürchler, N. (2002), Heilmittel für seltene Krankheiten: Schlüsel zu wirksamer Regulierung in der Schweiz, Aktuelle Juristische Praxis,8, 883-894.

Thiele, K.-P., Rheinberger, P. (2003): „Unmöglich“ gibt es nicht.

Therapiestudien auch bei seltenen Erkrankungen notwendig - und durchführbar. DÄB 16, 880-882.

Tirole, J. (1988), The Theory of Industrial Organization, MIT Press.

U.S. Congress. (2002): Best Pharmaceuticals for Children Act (BPCA). Public Law 107-109.

U.S. Congress. (2003): Pediatric Research Equity Act of 2003. Public Law 108155.

Van de Ven, A. (1988): Approaches to Innovation and Organzising. In: M. L. Tushman and W. L. More (Eds.), Readings in the Management if Innovations, Cambridge (Mas.).

Vitiello B., Heiligenstein, J H., Riddle, M. A. Greenhill, L. L. Fegert, J. M. (2004): The Interface Between Publicy Funded and Industry Funded Research in Pediatric Psychopharmacology: Opportunities for Integration and Collaboration, in press

Vitiello, B., Jensen, P. S. (1997): Medication development and testing in children and adolescents. Arch Gen Psychiatry 54:871-876.

Vollmann, J. (2000): Aufklärung und Einwilligung in der Psychiatrie. Ein Beitrag zu Ethik in der Medizin. Darmstadt.

Weiss Roberts, L., Roberts, B. (1999): „Psychiatric Research Ethics: An Overview of Evolving Guidelines and Current Ethical Dilemmas in the Study of Mental Illness“. Biol. Psychiatry 46, 1025-1038.

Wichert, Peter von: Terminologie/Programme: Die unwirkliche Wirklichkeit der Medizin. Dtsch Arztebl 2003; 100: A 104-107 [Heft 3]

Zito, J. M., Safer, D. J., dosReis, S., Magder, L. S., Gardner, J. F., Zarin, D. A. (1999): Psychotherapeutic medication patterns for youths with attentiondeficit/hyperactivity disorder. Arch Pediatr Adolesc Med 153:1257-1263. 